\title{
Standardized Library of Atrial Fibrillation Outcome
} Measures
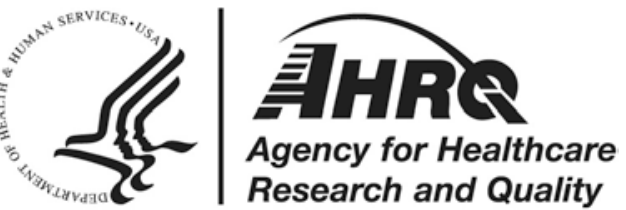


\section{Standardized Library of Atrial Fibrillation Outcome Measures}

Prepared for:

Agency for Healthcare Research and Quality

U.S. Department of Health and Human Services

5600 Fishers Lane

Rockville, MD 20857

www.ahrq.gov

Contract No. 290-2014-00004-C

Prepared by:

L\&M Policy Research, LLC

Washington, DC

With partner: OM1, AcademyHealth

Investigators:

Richard E. Gliklich, $\mathrm{MD}^{1}$

Michelle B. Leavy, $\mathrm{MPH}^{1}$

Fang Li, MD, MS ${ }^{1}$

${ }^{1} \mathrm{OM} 1$

AHRQ Publication No. 18(19)-EHC026-EF

November 2018 
This report is based on research conducted by the Agency for Healthcare Research and Quality (AHRQ) Evidence-based Practice Centers' Methods Workgroup. The findings and conclusions in this document are those of the authors, who are responsible for its contents; the findings and conclusions do not necessarily represent the views of AHRQ. Therefore, no statement in this report should be construed as an official position of AHRQ or of the U.S. Department of Health and Human Services.

\section{None of the investigators have any affiliations or financial involvement that conflicts with the material presented in this report.}

The information in this report is intended to help EPCs and AHRQ understand health-systems need and use of evidence to inform their decisionmaking. This report is not intended to be a substitute for the application of clinical judgment. Anyone who makes decisions concerning the provision of clinical care should consider this report in the same way as any medical reference and in conjunction with all other pertinent information, i.e., in the context of available resources and circumstances presented by individual patients.

This report is made available to the public under the terms of a licensing agreement between the authors and the Agency for Healthcare Research and Quality. This report may be used and reprinted without permission except those copyrighted materials that are clearly noted in the report. Further reproduction of those copyrighted materials is prohibited without the express permission of copyright holders.

AHRQ or U.S. Department of Health and Human Services endorsement of any derivative products that may be developed from this report, such as clinical practice guidelines, other quality enhancement tools, or reimbursement or coverage policies, may not be stated or implied.

Persons using assistive technology may not be able to fully access information in this report. For assistance contact epc@ahrq.hhs.gov.

Suggested citation: Gliklich RE, Leavy MB, Li F. Standardized Library of Atrial Fibrillation Outcome Measures. Research White Paper. (Prepared by L\&M Policy Research, LLC under Contract No. 290-2014-00004-C.) AHRQ Publication No. 18(19)-EHC026-EF. Rockville, MD: Agency for Healthcare Research and Quality; November 2018. Posted final reports are located on the Effective Health Care Program search page.

DOI: https://doi.org/10.23970/AHRQEPCWHITEPAPERHARMONIZATION. 


\section{Preface}

The Agency for Healthcare Research and Quality (AHRQ), through its Evidence-based Practice Centers (EPCs), sponsors the development of evidence reports and technology assessments to assist public- and private-sector organizations in their efforts to improve the quality of health care in the United States.

The reports and assessments provide organizations with comprehensive, science-based information on common, costly medical conditions and new health care technologies and strategies. The EPCs systematically review the relevant scientific literature on topics assigned to them by AHRQ and conduct additional analyses when appropriate prior to developing their reports and assessments.

To improve the scientific rigor of these evidence reports, AHRQ supports empiric research by the EPCs to help understand or improve complex methodologic issues in systematic reviews. These methods research projects are intended to contribute to the research base in and be used to improve the science of systematic reviews. They are not intended to be guidance to the EPC program, although may be considered by EPCs along with other scientific research when determining EPC program methods guidance.

AHRQ expects that the EPC evidence reports and technology assessments will inform individual health plans, providers, and purchasers as well as the health care system as a whole by providing important information to help improve health care quality. The reports undergo peer review prior to their release as a final report.

If you have comments on this Methods Research Project they may be sent by mail to the Task Order Officer named below at: Agency for Healthcare Research and Quality, 5600 Fishers Lane, Rockville, MD 20857, or by email to epc@ahrq.hhs.gov.

Gopal Khanna, M.B.A

Director

Agency for Healthcare Research and Quality

Stephanie Chang, M.D., M.P.H.

Director

Evidence-based Practice Center Program

Center for Evidence and Practice Improvement

Agency for Healthcare Research and Quality
Arlene Bierman, M.D., M.S.

Director

Center for Evidence and Practice Improvement

Agency for Healthcare Research and Quality

Elise Berliner, Ph.D.

Task Order Officer

Center for Evidence and Practice

Improvement

Agency for Healthcare Research and Quality 


\section{Contents}

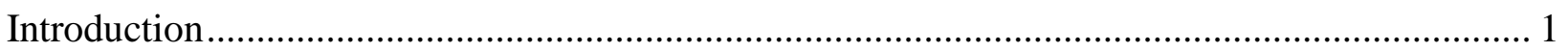

Approach to Representing an Outcome Definition................................................................. 2

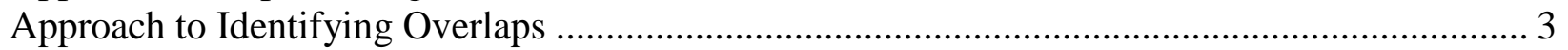

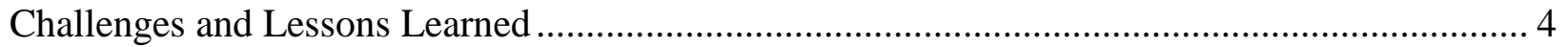

\section{Appendixes}

Appendix A. Harmonized Definitions for Atrial Fibrillation Outcome Measures

Appendix B. Standardized Library of Atrial Fibrillation Outcome Measures (posted separately) 


\section{Introduction}

Significant variation exists in both the types and definitions of outcome measures used in patient registries, even within the same clinical area. This variation reduces the utility of registries, making it difficult to compare, link, and aggregate data across the spectrum of clinical care and reporting. To address these limitations, the Agency for Healthcare Research and Quality (AHRQ) developed the Outcome Measures Framework (OMF), a conceptual model for classifying outcomes that are relevant to patients and providers across most conditions; it is intended to serve as a content model for developing harmonized outcome measures for specific

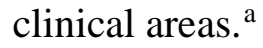

AHRQ is assessing the feasibility of using the OMF to develop standardized libraries of outcome measures in five clinical areas, including (1) Atrial fibrillation, (2) Asthma, (3) Depression, (4) Lung cancer, and (5) Lumbar spondylolisthesis. ${ }^{b}$ These clinical areas represent diverse populations and care settings, different treatment modalities, and varying levels of harmonization. For each clinical area, the relevant registries and observational studies are identified, and registry sponsors, informaticists, and clinical subject matter experts are invited to participate in a registry group that focuses on harmonizing outcome measures through a series of in-person and web-based meetings. A stakeholder group, including payers, patient representatives, Federal partners and health system leaders, is also assembled to discuss challenges and provide feedback on the harmonization effort.

A key goal of this effort is to standardize the definitions of the components that make up the outcome measures, so users can understand the level of comparability between measures across different systems and studies. As a final step in the harmonization process, clinical informaticists map the narrative definitions (generated by the workgroups) to standardized terminologies to produce a library of common data definitions.

This document describes the technical approach used to prepare the Standardized Library of Atrial Fibrillation Outcome Measures workbook. For reference, the narrative definitions for the minimum set of outcome measures produced by the Atrial Fibrillation Workgroup are included in Appendix A. The harmonization methodology and rationale for the measure definitions are discussed in a related publication. ${ }^{\mathrm{c}}$

\footnotetext{
${ }^{a}$ Gliklich RE, Leavy MB, Karl J, et al. A framework for creating standardized outcome measures for patient registries. Journal of Comparative Effectiveness Research. 2014;3(5):473-80.

bThis work was supported by the Office of the Secretary Patient-Centered Outcomes Research Trust Fund under Interagency Agreement \#16-566R-16.

${ }^{\mathrm{C} C a l k i n s ~ H, ~ G l i k l i c h ~ R E, ~ L e a v y ~ M B, ~ e t ~ a l . ~ H a r m o n i z e d ~ O u t c o m e ~ M e a s u r e s ~ f o r ~ U s e ~ i n ~ A t r i a l ~ F i b r i l l a t i o n ~ P a t i e n t ~}$ Registries and Clinical Practice. Heart Rhythm. Nov. 15, 2018. [Epub before print.]

https://www.heartrhythmjournal.com/article/S1547-5271(18)30948-2/fulltext
} 


\section{Approach to Representing an Outcome Definition}

For each measure, the accompanying workbook (Appendix B) contains the narrative definition and recommended reporting period (timeframe), the initial population for measurement (e.g., all atrial fibrillation patients, atrial fibrillation patients undergoing procedures), the outcome focused population (patients who experienced the outcome of interest), and the data criteria and value sets.

Electronic Health Record (EHR) data often will not contain all the requisite components of an outcome definition that would allow for the computational confirmation of that outcome. The approach used for this project is to gather the clinician's assertion of an outcome condition and as much supporting evidence as possible, so that even where the expression logic cannot computationally confirm an outcome, some structured evidence might still be available.

Relationships between events raise a challenge because relationships are often not directly asserted in an EHR. Thus, where possible, relationships have been inferred based on time stamps and intervals. Where this is not possible (e.g., cause of death), the logic requires an asserted relationship.

For each outcome, the following have been defined:

- An object representing the outcome condition itself: In many cases, the only structured data will be an assertion of an outcome, with all the supporting evidence being present in the narrative.

- Fast Healthcare Interoperability Resources (FHIR) for evidence for the outcome: These include labs, diagnostic imaging, etc.

- FHIR for additional relevant events: These might include procedures, encounters, etc.

- Temporal aspects for all events: These allow for inferred relationships. 


\section{Approach to Identifying Overlaps}

A key goal of this project is to leverage existing resources and build connections across initiatives, where possible. To support that goal, the following sources were searched for overlap:

- https://ecqi.healthit.gov/: Primarily looking for overlapping criteria

- https://vsac.nlm.nih.gov/: Primarily looking for overlapping value sets

- C-CDA: Primarily looking for overlapping data representations

- https://www.nlm.nih.gov/cde/: Primarily looking for overlapping data element definitions

Each site has a specific, unique purpose, and data representations vary, so while there are some direct comparisons with similar use cases, there are also important differences both in terms of data structures and in terms of use cases. Results of the comparisons are provided below.

- https://ecqi.healthit.gov/; https://vsac.nlm.nih.gov/:

o We were unable to identify any quality measures that laid out specific criteria for any of the atrial fibrillation outcomes. Quality measures generally look to the EHR problem list for an assertion that an outcome exists and generally do not attempt to define the detailed criteria for an outcome. For example, considering transient ischemic attack (TIA), quality measures will look for the presence of TIA on the problem list and do not require detailed supporting observations. Quality measures do create value sets (e.g., for TIA), and we did identify several overlapping value sets. All such value sets are housed at VSAC.

o eCQMs are based on the National Quality Forum's Quality Data Model, as expressed as HL7 QRDA templates, whereas this project is based on FHIR version 1.8.0 objects. ${ }^{\mathrm{d}}$ The HL7 Clinical Quality Improvement committee is actively harmonizing QDM and FHIR resources, and a FHIR-based quality reporting format is expected to be balloted soon.

o VSAC does not currently provide intentionally defined value sets. Therefore, comparisons are done based on enumerated lists.

- C-CDA:

o There are no atrial fibrillation or cardiac-specific templates or value sets in C-CDA.

- https://www.nlm.nih.gov/cde/:

o We were unable to identify any data elements that laid out specific criteria for any of the atrial fibrillation outcomes. Common data elements (CDEs) generally look for presence/absence of a condition and may associate a condition with a code system or value set. Therefore, there was minimal overlap between any atrial fibrillation outcomes and existing CDEs.

\footnotetext{
d http://hl7.org/fhir/2017Jan/index.html
} 


\section{Challenges and Lessons Learned}

Three challenges were encountered in translating the narrative definitions produced by the workgroup into standardized terminologies. First, the definitions for procedure-related death and major complications include the concept of complications related to a procedure or treatment. It is possible within an EHR setting to identify that an event occurred, but it is difficult and often not feasible to determine the cause of the event unless the event is recorded specifically as a procedure complication. For other events, it is feasible to identify an event that occurs in a specified time window after a procedure or treatment, but the event is not linked specifically to the procedure as a complication. In these cases, causality is assumed based on the nature of the event and the timing.

Second, it is difficult to determine whether a complication is 'major,' as defined in the major complications outcome measure. The criteria that distinguish a major complication, as specified in the definition, are 'permanent injury or death, requires intervention for treatment, or prolongs or requires hospitalization for more than 48 hours or results in re-hospitalization within 30 days.' Within the EHR setting, 'permanent' injury is not indicated; it may be assumed for events with no end date. It is also not feasible in most cases to determine if a specific complication prolonged a hospital stay.

Lastly, some definitions did not include sufficient specificity to produce standardized definitions. For example, the major bleeding definition uses 'e.g.,' rather than listing all possible critical areas or organs. Timeframe should also be specified clearly; as an example, the major bleeding definition references a hemoglobin drop of $2 \mathrm{~g} / \mathrm{dL}$, but does not specify the timeframe in which the two measurements must occur in order for the drop to count as major bleeding.

The project team will apply these lessons learned in subsequent workgroups. 


\section{Appendix A. Harmonized Definitions for Atrial Fibrillation Outcome Measures}

\begin{tabular}{|c|c|c|c|}
\hline $\begin{array}{c}\text { OMF } \\
\text { CATEGORY }\end{array}$ & $\begin{array}{l}\text { OUTCOME } \\
\text { MEASURE }\end{array}$ & DEFINITION & REFERENCE \\
\hline Survival & $\begin{array}{l}\text { All-cause } \\
\text { mortality }\end{array}$ & All-cause mortality & Workgroup recommendation \\
\hline Survival & $\begin{array}{l}\text { Cardiovascular } \\
\text { death }\end{array}$ & $\begin{array}{l}\text { Cardiovascular death indicates cause of death was sudden cardiac death, MI, } \\
\text { unstable angina, or other coronary artery disease; vascular death (e.g., stroke, arterial } \\
\text { embolism, pulmonary embolism, ruptured aortic aneurysm, or dissection); congestive } \\
\text { heart failure; or cardiac arrhythmia. }\end{array}$ & $\begin{array}{c}2004 \text { ACC/AHA Key Data } \\
\text { Elements (1) }\end{array}$ \\
\hline Survival & $\begin{array}{l}\text { Procedure-related } \\
\text { death }\end{array}$ & $\begin{array}{l}\text { All-cause mortality within } 30 \text { days of the procedure or during the index procedure } \\
\text { hospitalization (if the postoperative length of stay is }>\text { than } 30 \text { days). Procedure- } \\
\text { related deaths include those related to a complication of the procedure or treatment } \\
\text { for a complication of the procedure. }\end{array}$ & VARC Statement (2) \\
\hline $\begin{array}{l}\text { Clinical } \\
\text { Response }\end{array}$ & $\begin{array}{l}\text { AF/AFL/AT } \\
\text { Recurrence }\end{array}$ & $\begin{array}{c}\text { Recurrent AF/AFL/AT is defined as AF/AFL/AT of at least } 30 \text { seconds' duration that is } \\
\text { documented by an ECG or device recording system and occurs following catheter } \\
\text { ablation or drug therapy. In the setting of catheter ablation, recurrent AF/AFL/AT may } \\
\text { occur within or following the post ablation 3-month blanking period. Recurrent } \\
\text { AF/AFL/AT that occurs within the post ablation blanking period is not considered a } \\
\text { failure of AF ablation. }\end{array}$ & $\begin{array}{l}2017 \text { HRS Consensus } \\
\text { Statement (3) }\end{array}$ \\
\hline $\begin{array}{l}\text { Clinical } \\
\text { Response }\end{array}$ & $\begin{array}{l}\text { AF progression } \\
\text { (paroxysmal to } \\
\text { persistent AF) }\end{array}$ & $\begin{array}{c}\text { AF should be classified as paroxysmal or persistent in accordance with the } 2014 \\
\text { AHA/ACC/HRS joint committee guidelines on the management of patients with AF: } \\
\text { Paroxysmal AF: AF that terminates spontaneously or with intervention within } 7 \text { days of } \\
\text { onset. Episodes may recur with variable frequency. } \\
\text { Persistent AF: Continuous AF that is sustained }>7 \text { days. } \\
\text { Progression occurs when patients previously classified as paroxysmal AF are } \\
\text { classified as persistent AF. }\end{array}$ & $\begin{array}{c}\text { Modified from } 2014 \\
\text { AHA/ACC/HRS joint } \\
\text { committee guidelines on the } \\
\text { management of patients with } \\
\text { AF (4) } \\
\text { Definition of progression is } \\
\text { adapted from Padfield et al. } \\
\text { (5) }\end{array}$ \\
\hline
\end{tabular}




\begin{tabular}{|c|c|c|c|}
\hline $\begin{array}{c}\text { OMF } \\
\text { CATEGORY }\end{array}$ & $\begin{array}{l}\text { OUTCOME } \\
\text { MEASURE }\end{array}$ & DEFINITION & REFERENCE \\
\hline $\begin{array}{l}\text { Clinical } \\
\text { Response }\end{array}$ & $\begin{array}{l}\text { Thromboembolic } \\
\text { events (with } \\
\text { respect to } \\
\text { persistent AF } \\
\text { management) }\end{array}$ & $\begin{array}{l}\text { Stroke: An acute episode of focal or global neurological dysfunction caused by brain, } \\
\text { spinal cord, or retinal vascular injury as a result of hemorrhage or infarction. } \\
\text { Symptoms or signs must persist } \geq 24 \text { hours, or if documented by CT, MRI or autopsy, } \\
\text { the duration of symptoms/signs may be less than } 24 \text { hours. Stroke may be classified } \\
\text { as ischemic (including hemorrhagic transformation of ischemic stroke), hemorrhagic, } \\
\text { or undetermined. Stroke disability measurement should be performed using the } \\
\text { modified Rankin Scale (mRS) at discharge and } 6 \text { months post-discharge. The mRS } \\
\text { scores should be recorded. } \\
\text { Transient Ischemic Attack: Transient episode of focal neurological dysfunction caused } \\
\text { by brain, spinal cord, or retinal ischemia without acute infarction and with signs and } \\
\text { symptoms lasting less than } 24 \text { hours. } \\
\text { Systemic embolism: Acute arterial insufficiency or occlusion of the extremities or any } \\
\text { non-CNS organ associated with clinical, imaging, surgical/autopsy evidence of arterial } \\
\text { occlusion in the absence of other likely mechanism (e.g., trauma, atherosclerosis, or } \\
\text { instrumentation). }\end{array}$ & Workgroup recommendation \\
\hline $\begin{array}{l}\text { Events of } \\
\text { Interest }\end{array}$ & Stroke & $\begin{array}{l}\text { An acute episode of focal or global neurological dysfunction caused by brain, spinal } \\
\text { cord, or retinal vascular injury as a result of hemorrhage or infarction. Symptoms or } \\
\text { signs must persist } \geq 24 \text { hours, or if documented by CT, MRI or autopsy, the duration of } \\
\text { symptoms/signs may be less than } 24 \text { hours. Stroke may be classified as ischemic } \\
\text { (including hemorrhagic transformation of ischemic stroke), hemorrhagic, or } \\
\text { undetermined. Stroke disability measurement should be performed using the modified } \\
\text { Rankin Scale (mRS) at discharge and } 6 \text { months post-discharge. The mRS scores } \\
\text { should be recorded. }\end{array}$ & $\begin{array}{c}2014 \text { ACC/AHA Key Data } \\
\text { Elements (6) }\end{array}$ \\
\hline $\begin{array}{l}\text { Events of } \\
\text { Interest }\end{array}$ & TIA & $\begin{array}{l}\text { Transient episode of focal neurological dysfunction caused by brain, spinal cord, or } \\
\text { retinal ischemia without acute infarction and with signs and symptoms lasting less } \\
\text { than } 24 \text { hours. }\end{array}$ & $\begin{array}{c}2014 \text { ACC/AHA Key Data } \\
\text { Elements (6) }\end{array}$ \\
\hline $\begin{array}{l}\text { Events of } \\
\text { Interest }\end{array}$ & $\begin{array}{l}\text { Systemic } \\
\text { embolism }\end{array}$ & $\begin{array}{l}\text { Acute arterial insufficiency or occlusion of the extremities or any non-CNS organ } \\
\text { associated with clinical, imaging, surgical/autopsy evidence of arterial occlusion in the } \\
\text { absence of other likely mechanism (e.g., trauma, atherosclerosis, or instrumentation). }\end{array}$ & $\begin{array}{l}\text { Modified from the Munich } \\
\text { Consensus Statement ( } 7 \text { ) }\end{array}$ \\
\hline $\begin{array}{l}\text { Events of } \\
\text { Interest }\end{array}$ & $\begin{array}{l}\text { Major bleeding at } \\
12 \text { month interval } \\
\text { of interest (no } \\
\text { peri-procedural } \\
\text { association) }\end{array}$ & $\begin{array}{c}\text { Fatal bleeding AND/OR symptomatic bleeding in a critical area or organ, such as } \\
\text { intracranial, intraspinal, intraocular, retroperitoneal, intraarticular, pericardial, or } \\
\text { intramuscular with compartment syndrome AND/OR bleeding causing a fall in } \\
\text { hemoglobin level of } 2 \mathrm{~g} / \mathrm{dL} \text { (1.24 mmol/L) or more, or leading to transfusion of two or } \\
\text { more units of blood. }\end{array}$ & ISTH definition (8) \\
\hline
\end{tabular}




\begin{tabular}{|c|c|c|c|}
\hline $\begin{array}{c}\text { OMF } \\
\text { CATEGORY }\end{array}$ & $\begin{array}{l}\text { OUTCOME } \\
\text { MEASURE }\end{array}$ & DEFINITION & REFERENCE \\
\hline $\begin{array}{l}\text { Events of } \\
\text { Interest }\end{array}$ & $\begin{array}{l}\text { Periprocedural } \\
\text { bleeding (any } \\
\text { bleeding during } \\
\text { 12-month interval } \\
\text { which occurs } \\
\text { within 30d of } \\
\text { procedure) }\end{array}$ & $\begin{array}{l}\text { Major bleeding: Fatal bleeding AND/OR symptomatic bleeding in a critical area or } \\
\text { organ, such as intracranial, intraspinal, intraocular, retroperitoneal, intraarticular, } \\
\text { pericardial, or intramuscular with compartment syndrome AND/OR bleeding causing a } \\
\text { fall in hemoglobin level of } 2 \mathrm{~g} / \mathrm{dL}(1.24 \mathrm{mmol} / \mathrm{L}) \text { or more, or leading to transfusion of } \\
\text { two or more units of blood. } \\
\text { Clinically relevant non-major bleeding: An acute or subacute clinically overt bleed that } \\
\text { does not meet the criteria for a major bleed but prompts a clinical response such that it } \\
\text { leads to one of the following: hospital admission for bleeding; physician- guided } \\
\text { medical or surgical treatment for bleeding; change in antithrombotic therapy (including } \\
\text { interruption or discontinuation). } \\
\text { Minor bleeding: All nonmajor bleeds. Minor bleeds are further divided into clinically } \\
\text { relevant and not. } \\
\text { Note: Registries should clearly report how they communicate with patients (phone, in- } \\
\text { person visit) to obtain information on bleeding events. }\end{array}$ & ISTH definition (8) \\
\hline
\end{tabular}




\begin{tabular}{|c|c|c|c|}
\hline $\begin{array}{l}\text { OMF } \\
\text { CATEGORY }\end{array}$ & $\begin{array}{l}\text { OUTCOME } \\
\text { MEASURE }\end{array}$ & DEFINITION & REFERENCE \\
\hline $\begin{array}{l}\text { Events of } \\
\text { Interest }\end{array}$ & $\begin{array}{l}\text { Myocardial } \\
\text { infarction }\end{array}$ & $\begin{array}{l}\text { The term acute myocardial infarction (MI) should be used when there is evidence of } \\
\text { myocardial necrosis in a clinical setting consistent with acute myocardial ischemia. } \\
\text { Under these conditions any one of the following criteria meets the diagnosis for MI: } \\
\text { Detection of a rise and/or fall of cardiac biomarker values [preferably cardiac troponin } \\
\text { (cTn)] with at least one value above the 99th percentile upper reference limit (URL) } \\
\text { and with at least one of the following: } \\
\text { Symptoms of ischemia } \\
\text { Dew or presumed new significant ST-segment-T wave (ST-T) changes or new left } \\
\text { bundle branch block (LBBB). } \\
\text { Development of pathological Q waves in the ECG. } \\
\text { Imaging evidence of new loss of viable myocardium or new regional wall motion } \\
\text { Identification of an intracoronary thrombus by angiography or autopsy. } \\
\text { Cardiac death with symptoms suggestive of myocardial ischemia and presumed new } \\
\text { ischemic ECG changes or new LBBB, but death occurred before cardiac biomarkers } \\
\text { were obtained, or before cardiac biomarker values would be increased. } \\
\text { Percutaneous coronary intervention (PCI) related MI is arbitrarily defined by elevation } \\
\text { of cTn values (>5 } \mathrm{X} \text { 99th percentile URL) in patients with normal baseline values ( } 99 \text { th } \\
\text { percentile URL) or a rise of cTn values >20\% if the baseline values are elevated and } \\
\text { are stable or falling. In addition, either (i) symptoms suggestive of myocardial ischemia } \\
\text { or (ii) new ischemic ECG changes or (iii) angiographic findings consistent with a } \\
\text { procedural complication or (iv) imaging demonstration of new loss of viable } \\
\text { myocardium or new regional wall motion abnormality are required. } \\
\text { Stent thrombosis associated with MI when detected by coronary angiography or } \\
\text { autopsy in the setting of myocardial ischemia and with a rise and/or fall of cardiac } \\
\text { biomarker values with at least one value above the 99th percentile URL. } \\
\text { Coronary artery bypass grafting (CABG) related MI is arbitrarily defined by elevation of } \\
\text { cardiac biomarker values (>10 x } 99 \text { th percentile URL) in patients with normal baseline } \\
\text { new LBBB, or (ii) angiographic documented new graft or new native coronary artery } \\
\text { occlusion, or (iii) imaging evidence of new loss of viable myocardium or new regional } \\
\text { wall motion abnormality. }\end{array}$ & $\begin{array}{l}\text { Third universal definition of } \\
\text { myocardial infarction (9) }\end{array}$ \\
\hline
\end{tabular}




\begin{tabular}{|c|c|c|c|}
\hline $\begin{array}{l}\text { OMF } \\
\text { CATEGORY }\end{array}$ & $\begin{array}{l}\text { OUTCOME } \\
\text { MEASURE }\end{array}$ & DEFINITION & REFERENCE \\
\hline $\begin{array}{l}\text { Events of } \\
\text { Interest }\end{array}$ & $\begin{array}{l}\text { Myocardial } \\
\text { infarction (as a } \\
\text { complication of } \\
\text { ablation } \\
\text { procedure) }\end{array}$ & $\begin{array}{l}\text { MI, in the context of catheter or surgical ablation, is defined as the presence of any } \\
\text { one of the following criteria: (1) detection of ECG changes indicative of new ischemia } \\
\text { (new ST-T changes or new LBBB) that persist for more than } 1 \text { hour; (2) development } \\
\text { of new pathological Q waves on an ECG; (3) imaging evidence of new loss of viable } \\
\text { myocardium or new regional wall motion abnormality. }\end{array}$ & $\begin{array}{l}2017 \text { HRS Consensus } \\
\text { statement (3) }\end{array}$ \\
\hline $\begin{array}{l}\text { Events of } \\
\text { Interest }\end{array}$ & Heart Failure & $\begin{array}{l}\text { Heart failure is defined as physician documentation or report of any of the following } \\
\text { clinical symptoms of heart failure described as unusual dyspnea on light exertion, } \\
\text { recurrent dyspnea occurring in the supine position, fluid retention; or the description of } \\
\text { rales, jugular venous distention, or pulmonary edema on physical examination. A low } \\
\text { ejection fraction without clinical presentation does not qualify as heart failure. Studies } \\
\text { that wish to classify heart failure should use the New York Heart Association (NYHA) } \\
\text { Functional Classification. }\end{array}$ & $\begin{array}{l}2013 \text { ACCF/AHA key data } \\
\text { elements and definitions (9) }\end{array}$ \\
\hline $\begin{array}{l}\text { Events of } \\
\text { Interest }\end{array}$ & $\begin{array}{l}\text { Other major } \\
\text { complications of } \\
\text { the procedure }\end{array}$ & $\begin{array}{l}\text { A major complication is a complication results in permanent injury or death, requires } \\
\text { intervention for treatment, or prolongs or requires hospitalization for more than } 48 \\
\text { hours or results in re-hospitalization within } 30 \text { days. } \\
\text { Because early recurrences of AF/AFL/AT are to be expected following AF ablation, } \\
\text { recurrent AF/AFL/AT within } 3 \text { months that requires or prolongs a patient's } \\
\text { hospitalization should not be considered to be a major complication of AF ablation. } \\
\text { Because early recurrences of AF/AFL/AT following antiarrhythmic drug therapy are a } \\
\text { failure of therapy and not a complication, they should be excluded from this measure } \\
\text { as it relates to prolonged hospitalization or readmission within } 30 \text { days. }\end{array}$ & $\begin{array}{l}2017 \text { HRS Consensus } \\
\text { Statement (3) }\end{array}$ \\
\hline $\begin{array}{l}\text { Patient } \\
\text { Reported }\end{array}$ & $\begin{array}{l}\text { AF-related quality } \\
\quad \text { of life }\end{array}$ & $\begin{array}{l}\text { AF-related quality of life should be measured using an AF-specific quality of life } \\
\text { instrument that is validated and commonly used, such as AFEQT. }\end{array}$ & Workgroup recommendation \\
\hline $\begin{array}{l}\text { Patient } \\
\text { Reported }\end{array}$ & $\begin{array}{l}\text { Generic quality of } \\
\quad \text { life }\end{array}$ & $\begin{array}{l}\text { General quality of life should be measured using a quality of life instrument that is } \\
\text { validated and commonly used. }\end{array}$ & Workgroup recommendation \\
\hline $\begin{array}{l}\text { Resource } \\
\text { Utilization }\end{array}$ & $\begin{array}{l}\text { All-cause } \\
\text { hospitalization }\end{array}$ & All-cause hospitalization & Workgroup recommendation \\
\hline $\begin{array}{l}\text { Resource } \\
\text { Utilization }\end{array}$ & $\begin{array}{l}\text { Cause-specific } \\
\text { hospitalization }\end{array}$ & $\begin{array}{l}\text { Hospitalization for which the primary admitting diagnosis was for heart failure, stroke, } \\
\text { bleeding, atrial fibrillation, repeat AF-ablations, periprocedural complication, other } \\
\text { cardiovascular causes. }\end{array}$ & Workgroup recommendation \\
\hline
\end{tabular}


OMF OUTCOME MEASURE

\section{REFERENCE}

Resource Other resource utilization related

Other resource utilization related to treatment or management of AF or associated

Workgroup recommendation

Utilization

to treatment or

management of

AF or associated

complications 


\section{References}

1. McNamara RL, Brass LM, Drozda JPJ, et al. ACC/AHA key data elements and definitions for measuring the clinical management and outcomes of patients with atrial fibrillation: A report of the American College of Cardiology/American Heart Association Task Force on Clinical Data Standards (Writing Commitee to Develop Data Standards on Atrial Fibrillation). J Am Coll Cardiol. 2004 Jul 21;44(2):475-95. DOI: 10.1016/j.jacc.2004.06.041.

2. Kappetein AP, Head SJ, Genereux P, et al. Updated standardized endpoint definitions for transcatheter aortic valve implantation: the Valve Academic Research Consortium-2 consensus document (VARC-2). J Am Coll Cardiol. 2012 Oct 9;60(15):1438-54. DOI: 10.1016/j.jacc.2012.09.001.

3. Calkins H, Hindricks G, Cappato R, et al. 2017 HRS/EHRA/ECAS/APHRS/ SOLAECE expert consensus statement on catheter and surgical ablation of atrial fibrillation. Heart Rhythm. 2017

Oct;14(10):e275-e444. DOI: 10.1016/j.hrthm.2017.05.012.

4. January CT, Wann LS, Alpert JS, et al. 2014 AHA/ACC/HRS guideline for the management of patients with atrial fibrillation: a report of the American College of Cardiology/American Heart Association Task Force on Practice Guidelines and the Heart Rhythm Society. J Am Coll Cardiol. 2014 Dec 2;64(21):e1-76. DOI: 10.1016/j.jacc.2014.03.022.
5. Padfield GJ, Steinberg C, Swampillai J, et al. Progression of paroxysmal to persistent atrial fibrillation: 10-year follow-up in the Canadian Registry of Atrial Fibrillation. Heart Rhythm. 2017 Jun;14(6):801-7. DOI: 10.1016/j.hrthm.2017.01.038.

6. Hicks KA, Tcheng JE, Bozkurt B, et al. 2014 ACC/AHA Key Data Elements and Definitions for Cardiovascular Endpoint Events in Clinical Trials. Circulation. 2015 Jul 27;132(4):302. DOI: 10.1161/CIR.0000000000000156.

7. Tzikas A, Holmes DRJ, Gafoor S, et al. Percutaneous left atrial appendage occlusion: the Munich consensus document on definitions, endpoints and data collection requirements for clinical studies. EuroIntervention 2016 May 17;12(1):10311. DOI: 10.4244/EIJV12I1A18.

8. Schulman S, Kearon C. Definition of major bleeding in clinical investigations of antihemostatic medicinal products in nonsurgical patients. J Thromb Haemost JTH. 2005 Apr;3(4):692-4. DOI: 10.1111/j.15387836.2005.01204.x

9. Cannon CP, Brindis RG, Chaitman BR, et al. 2013 ACCF/AHA key data elements and definitions for measuring the clinical management and outcomes of patients with acute coronary syndromes and coronary artery disease: a report of the American College of Cardiology Foundation/American Heart Association Task Force on Clinical Data Standards (Writing Committee to Develop Acute Coronary Syndromes and Coronary Artery Disease Clinical Data Standards). Circulation. 2013 Mar 5;127(9):1052-89. DOI: 10.1161/CIR.0b013e3182831a11. 